\title{
Linking size-based and trophic analyses of benthic community structure
}

\author{
Simon Jennings ${ }^{1, *}$, John K. Pinnegar ${ }^{1}$, Nicholas V. C. Polunin ${ }^{2}$, Karema J. Warr ${ }^{1}$ \\ ${ }^{1}$ Centre for Environment, Fisheries \& Aquaculture Science, Lowestoft Laboratory, Lowestoft NR33 0HT, United Kingdom \\ ${ }^{2}$ Department of Marine Sciences \& Coastal Management, University of Newcastle, Newcastle upon Tyne NE1 7RU, \\ United Kingdom
}

\begin{abstract}
Models of biomass size spectra assume that organisms with higher body mass feed at higher trophic levels, but explicit empirical tests of this pattern are rare. We used nitrogen stable isotopes $\left(\delta^{15} \mathrm{~N}\right)$ as an index of the trophic level in a benthic fish and invertebrate size-spectrum, and demonstrated that body mass was positively and significantly related to trophic level. This pattern was consistent with the expectation that predator-prey relationships led to powerful size-based trophic structuring in marine communities and ecosystems. Further analysis of intra- and interspecific relationships between body mass and trophic level in the community showed that increases in trophic level across the size spectrum were predominantly a consequence of intra-specific increases in trophic level with body mass and not a consequence of larger species (species with greater maximum body mass) feeding at higher trophic levels. We confirmed the absence of strong inter-specific relationships between maximum body mass and trophic level with cross-species and phylogenetic comparative approaches. Size-based models are easier and cheaper to parameterise than most food-web models. Subject to the persistence of relationships between body mass and trophic level in space and time, our results suggest that size spectra could be parameterised with body mass-trophic level relationships and used to describe the trophic structure of some marine communities and ecosystems.
\end{abstract}

KEY WORDS: Size-spectra · Trophic level · Food web · Community structure · Stable isotopes · Phylogeny Resale or republication not permitted without written consent of the publisher

\section{INTRODUCTION}

Biomass size-spectra are widely used to describe the structure of marine ecosystems (Sheldon et al. 1972, Pope et al. 1988, Duplisea \& Kerr 1995, Rice \& Gislason 1996, Duplisea 1998) and models of size-spectra assume that total biomass decreases in progressively heavier body-mass classes because there is inefficient energy transfer from prey to predators (Kerr 1974, Dickie et al. 1987, Boudreau et al. 1991, Thiebaux \& Dickie 1992, 1993). This implies that organisms with higher body mass feed at higher trophic levels, but explicit empirical tests of this pattern are rare (Fry \& Quinones 1994, France et al. 1998).

*E-mail: s.jennings@cefas.co.uk
Body mass is a fundamental attribute of any animal (Peters 1983). Species with lower adult body mass have higher intrinsic rates of increase (Schwinghamer et al. 1986), production (Brey 1990, 1999), reproductive output (Gunderson \& Dygert 1988, Charnov 1993) and natural mortality (Beverton \& Holt 1959, Pauly 1980). Differences in body mass within species also account for differences in growth, production and mortality, with smaller individuals growing faster and realising more production per unit body mass, but suffering higher natural mortality. Within a size spectrum, ecological processes such as production are treated solely as a function of body size, and thus a small individual of a large species is equivalent to a large individual of a small species in the same body mass class. 
Trophic level is expected to increase with increasing body size because, with the exception of parasites, most predators are larger than their prey (Cohen et al. 1993). However, this increase has been difficult to quantify since relationships between predator and prey species are highly transient in time. The transience results from the exceptional scope for growth within most marine species and the variability in growth within and among species (Brey 1999). For example, the body mass of many species increases by 5 orders of magnitude or more during their life (Cushing 1975) and a fast-growing species may begin life as a prey item for other species only to become the main predator on the same group of species within one year (Boyle \& Pierce 1994, Boyle \& Bolettzky 1996).

The transience of predator-prey interactions, in space as well as time (Kingsford 1992), makes the study of trophic relationships a data-intensive exercise. Even studies of predator-prey relationships within small well-studied groups of commercially exploited fish species have required stomach sampling on unprecedented scales (Magnússon 1995, ICES 1999). Such species-focused approaches are unlikely to help describe trophic relationships in larger communities and ecosystems. For this reason, descriptions of trophic structure that aggregate across individuals on the basis of size rather than species may provide desirable simplifications.

One impediment to the description of links between body size and trophic level is the problem of estimating the trophic level of species that switch diet frequently, prey on species that are digested at different rates, and have gut contents that cannot be clearly identified (Polunin \& Pinnegar 2002). Nitrogen stable isotope analysis provides an alternate method of estimating trophic level (Fry \& Sherr 1984, Minawaga \& Wada 1984, Owens 1987), because the abundance of $\delta^{15} \mathrm{~N}$ in the tissues of consumers is typically enriched by $3 \%$ relative to their prey (Peterson et al. 1985, Peterson \&
Fry 1987, Hobson \& Welch 1992, Fry \& Quinones 1994, Cabana \& Rasmussen 1996, Post et al. 2000). Moreover, the abundance of $\delta^{15} \mathrm{~N}$ reflects the composition of assimilated diet and integrates differences in assimilated diet over time (Hobson \& Welch 1992).

Nitrogen stable isotopes have already been used to provide evidence of links between trophic level and body mass in planktonic (Fry \& Quinones 1994) and benthic (France et al. 1998) communities and to provide evidence for intraspecific relationships between body size and trophic level (Rau et al. 1983, Sholtodouglas et al. 1991, Wainwright et al. 1993, Hentschel 1998, Lindsay et al. 1998, Persson \& Hansson 1999). We build on these observations to assess the roles of intraand inter-specific relationships between body mass and trophic level in governing the trophic structure of a benthic community. If body size does provide a surrogate for trophic level, then analyses of size-spectra could be used to describe changes in the trophic structure of marine communities and ecosystems. The aims of this study were (1) to determine whether body size class is a good predictor of trophic level in a benthic community, and (2) to assess the role of intra- and inter-specific size-related changes in trophic level in determining trophic structure. We used $\delta^{15} \mathrm{~N}$ as an index of trophic level.

\section{MATERIALS AND METHODS}

We investigated relationships between body size and $\delta^{15} \mathrm{~N}$ in the Silver Pit region of the central North Sea (Fig. 1). The Silver Pit is predominantly 50 to $80 \mathrm{~m}$ deep, with a muddy-sand substratum, and is surrounded by shallower sandy areas. Epibenthic fishes and invertebrates were sampled with a $2 \mathrm{~m}$ beam trawl fished from the RV 'Corystes'. Three randomly located replicate tows of $5 \mathrm{~min}$ duration were completed in each of seven $1 \times 1$ nautical mile boxes (Fig. 1). The
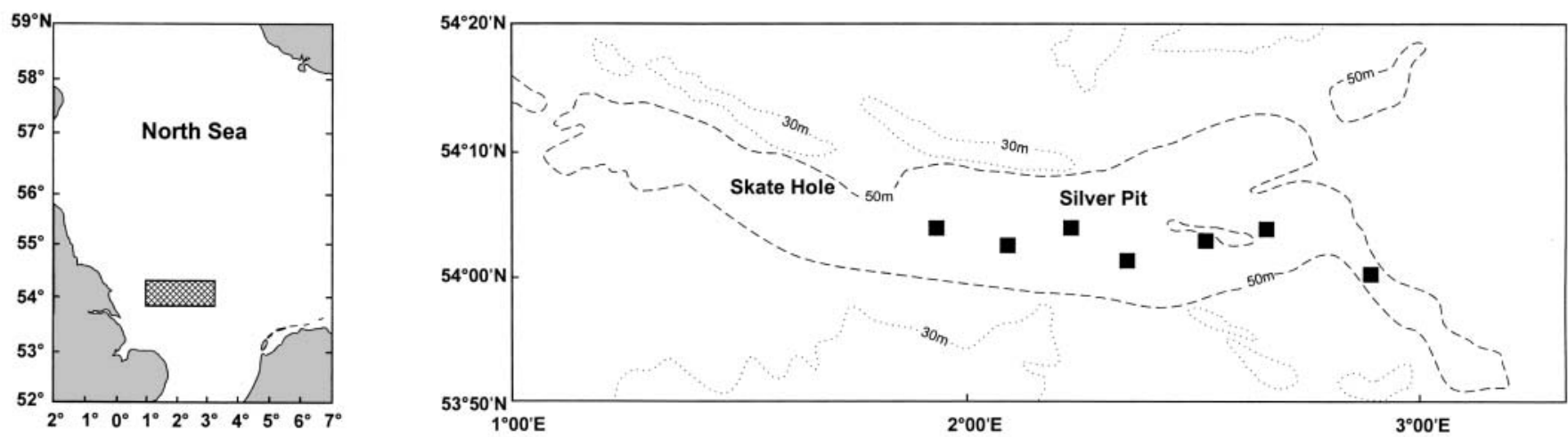

Fig. 1. The North Sea and the location of the Silver Pit study area (cross-hatched). Trawling was conducted in 7 boxes of $1 \times 1$ nautical mile (ם). Depth contours are shown at 30 and $50 \mathrm{~m}$ 
beam trawl was fitted with a chain mat and $2 \mathrm{~mm}$ mesh liner, and was towed at a speed of $1 \mathrm{knot}\left(1.85 \mathrm{~km} \mathrm{~h}^{-1}\right)$ with a warp length:water depth ratio of 3:1 (Jennings et al. 1999). Each tow was timed from the moment that the net contacted the seabed until the moment of hauling from the seabed. Operational constraints meant that the distance trawled had to be confirmed retrospectively, using Sextant software linked to the ship's Differential Global Positioning System (DGPS). All sampling was conducted from 29 October 1999 to 8 December 1999.

To describe relationships between body size and trophic level for whole communities, we estimated $\delta^{15} \mathrm{~N}$ by $\log _{2}$ body mass class. Catches from the 3 tows in each $1 \mathrm{n}$ mile ${ }^{2}$ box were pooled, and all free-living epibenthic invertebrates and fishes were weighed and assigned to $\log _{2}$ body mass classes from 0.0625 to 32.0 g. Free-living epibenthic invertebrates were defined as species that did not anchor to shell, stone, rock or sand and that lived on the seabed or burrowed into it temporarily. Free-living species dominate epifaunal biomass in the Silver Pit (Jennings et al. 2001). Since each $\log _{2}$ size class contained many animals of many species, comparable tissues could not be sampled, and all individuals in each size class were homogenised in an electric blender, usually with added water, to produce a thoroughly mixed suspension that poured smoothly. Approximately $7 \mathrm{ml}$ of this suspension was frozen to $-20^{\circ} \mathrm{C}$. The frozen suspension was freezedried to constant weight and ground to a fine powder (particles $<60 \mu \mathrm{m}$ ). The powder was thoroughly mixed and a $1 \mathrm{mg}$ sample weighed into a tin capsule for stable isotope analysis.

To investigate the relationship between body mass and $\delta^{15} \mathrm{~N}$ within species, we collected individuals spanning the range of observed sizes of each of the 10 most abundant species we recorded in the $2 \mathrm{~m}$ beam hauls (21 hauls). Individuals were collected in ten $2 \mathrm{~m}$ beam tows, each of 10 minutes duration. Each individual was weighed, macerated in an electric blender and frozen. Hermit crabs were removed from their shells before maceration. On return to the laboratory the frozen tissue was freeze-dried, ground and weighed into a capsule as described above.

To investigate the relationship between body mass and $\delta^{15} \mathrm{~N}$ among species, we had to extend our sampling area in space and time. A preliminary study demonstrated that variance in $\delta^{15} \mathrm{~N}$ among individuals of different sizes was greater than variance in $\delta^{15} \mathrm{~N}$ among sites for individuals of the same size. Given that individuals of the required body size (see below) could not always be caught in the Silver Pit (because they were rare), we extended our sampling time from 29 October 1999 to 4 December 2000, and our sampling area from the Silver Pit to $53^{\circ} 30^{\prime}-57^{\circ} 30^{\prime} \mathrm{N}$ and from 0 to $5^{\circ} \mathrm{E}$. Individual species of invertebrates were sampled with a GOV (Grande Ouverture Verticale) demersal otter trawl and $2 \mathrm{~m}$ beam trawl fished from the RV 'Cirolana' and with $2 \mathrm{~m}$ and $4 \mathrm{~m}$ beam trawls fished from 'Corystes'. The GOV and $4 \mathrm{~m}$ beam trawls were fitted with a cod-end liner of $20 \mathrm{~mm}$ stretched mesh, and tows of 30 minutes duration were made at a speed of approximately 4 knots.

To investigate the relationship between body mass and $\delta^{15} \mathrm{~N}$ among species, invertebrates from different species had to be compared at a similar stage of their life history. Because key events in the life history, such as maturity, occur at a relatively constant proportion of maximum size (Charnov 1993), and because mass is a good correlate of life history attributes such as production (Brey 1990, 1999), comparing species at a fixed proportion of maximum size is equivalent to comparing them at a specific stage of their life history. We attempted to sample individuals that were 40 to $60 \%$ of their potential maximum body mass. Hermit crabs (Paguridae) were weighed after removal from their shells, but animals that secreted their own carapace were weighed with the carapace intact. Bivalve and gastropod shells were removed before maceration. Three individuals of each species were macerated to obtain tissue samples for nitrogen stable isotope analysis. The macerated tissue was placed in a vial and immediately frozen to $-20^{\circ} \mathrm{C}$. On return to the laboratory the frozen tissue was freeze-dried, ground and weighed into a capsule as described above. Estimates of maximum body mass were the weights of the largest individuals observed in $>100$ hauls with $2 \mathrm{~m}$ beam, $4 \mathrm{~m}$ beam, and GOV trawls from 29 October 1999 to 4 December 2000.

Stable isotope analysis. The ${ }^{15} \mathrm{~N}$ composition of the ground tissue samples was determined using continuous flow isotope ratio-mass spectrometry (CF-IRMS) (Preston \& Owens 1983, Preston 1992). Samples were oxidised and the resulting $\mathrm{N}_{2}$ was passed to a single inlet dual collector mass spectrometer (Automated Nitrogen Carbon Analysis [ANCA] SL 20-20 or Integra systems). These were continuous-flow systems, so 2 samples of reference material (an internal standard) were analysed after every 5 tissue samples in order to calibrate the system and compensate for drift with time (ANCA-SL Dual Isotope software).

Ratios of ${ }^{15} \mathrm{~N}:{ }^{14} \mathrm{~N}$ were expressed relative to $\mathrm{N}_{2}$ in air for nitrogen and calculated as:

$$
\delta^{15} \mathrm{~N}=\left(\frac{{ }^{15} \mathrm{~N}:{ }^{14} \mathrm{~N}_{\text {sample }}}{{ }^{15} \mathrm{~N}:{ }^{14} \mathrm{~N}_{\text {standard }}}-1\right) \times 1000
$$

The mean $\delta^{15} \mathrm{~N}$ for the infaunal or epifaunal community at each site was calculated as a weighted mean of $\delta^{15} \mathrm{~N}$ by size class. Analyses were conducted at the University of Newcastle Biomedical Mass Spectroscopy 

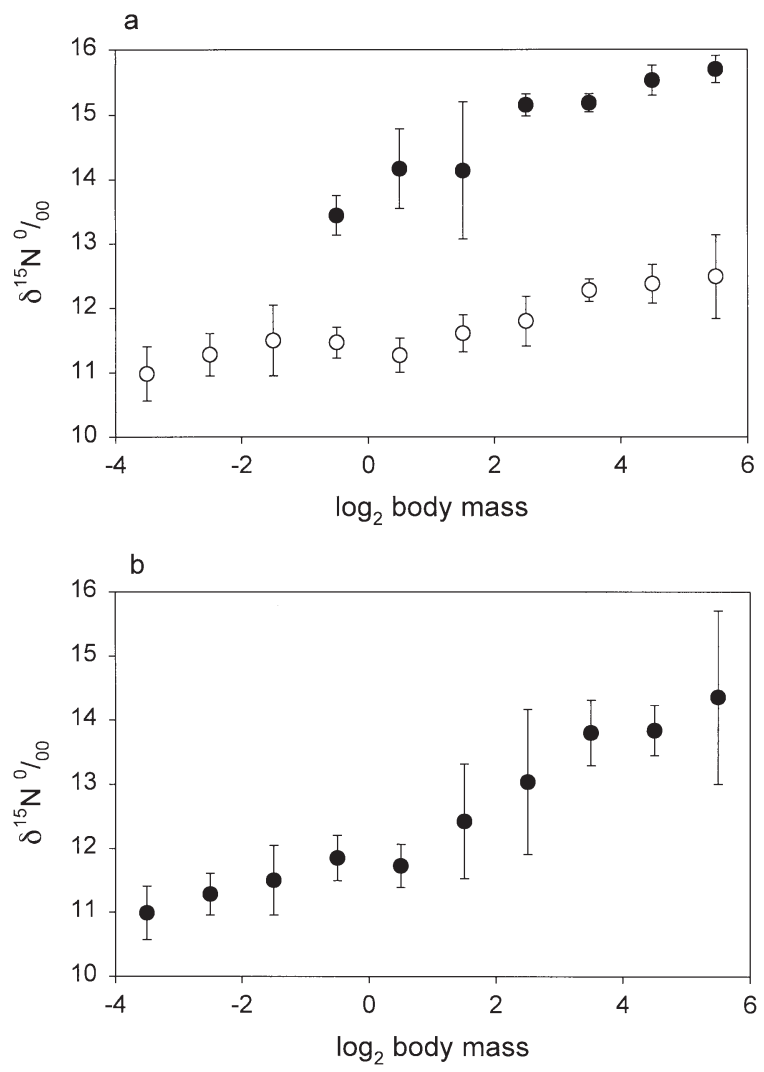

Fig. 2. Relationships between the mean $\delta^{15} \mathrm{~N}( \pm 95 \%$ CL) and $\log _{2}$ body mass class of (a) invertebrates (O) and fishes ( $\bullet$ ), and (b) combined invertebrates/fishes ( $\mathrm{n} \geq 5$ for all body mass classes)

Unit and at PDZ-Europa. In both laboratories, the SD for repeated $\delta^{15} \mathrm{~N}$ measurements with the reference material was $<0.15 \%$.

Data analysis. We used linear regression to explore cross-species relationships between maximum body mass and $\delta^{15} \mathrm{~N}$. In order to confirm that any significant relationships were not confounded by the non-independence of data used in the cross species analysis, the significance of relationships between body size and trophic level was also assessed using a comparative approach (Felsenstein 1985, Harvey \& Pagel 1991). Phylogenetically based analyses overcome the fact that related taxa may share traits due to common ancestry and yield data which are statistically independent (Harvey \& Pagel 1991). The comparative approach has already been used to assess links between the life histories and population biology of marine species (Jennings et al. 1998, Reynolds et al. 2001). Phylogenetic relationships among species were determined from taxonomic evidence (Hayward \& Ryland 1990a,b, Howson \& Picton 1997) because appropriate molecular phylogenies were not available. Independent differences (contrasts) in body mass within pairs of related species were calculated by sub- tracting the $\log _{2}$ maximum mass of the smaller species from the $\log _{2}$ maximum mass of the larger one. Preliminary analysis of the data showed that log transformation of mass removed the effects of the relationship between body mass and location in the phylogeny (Freckleton 2000). Contrasts in $\delta^{15} \mathrm{~N}$ were then calculated for the same species pair. Contrasts in mass were set to positive since the body size of the smaller species was always subtracted from the larger. If phylogenetic relationships between species could not be resolved, we calculated all $\left(n^{2}-n\right) / 2$ contrasts for each group and presented mean values. The significance of the relationship between contrast in maximum mass and contrast in $\delta^{15} \mathrm{~N}$ was assessed using binomial tests (Harvey \& Pagel 1991). The null expectation is that contrasts in $\delta^{15} \mathrm{~N}$ will be randomly distributed around zero when the contrast in body mass is set to positive.

\section{RESULTS}

The relationship between $\delta^{15} \mathrm{~N}$ and body mass (M) for the invertebrate community in the Silver Pit (Fig. 2a) was $\delta^{15} \mathrm{~N}=11.5+0.159 \log _{2} \mathrm{M}$, and this was significant $\left(\mathrm{r}^{2}=0.45, F_{1,67}=54.56, \mathrm{p}<0.001\right)$. The relationship between $\delta^{15} \mathrm{~N}$ and body mass for the fish community was $\delta^{15} \mathrm{~N}=13.9+0.364 \log _{2} \mathrm{M}$ and was also significant $\left(\mathrm{r}^{2}=0.70, F_{1,39}=92.63, \mathrm{p}<0.001\right)$. The relationship between $\delta^{15} \mathrm{~N}$ and body mass for the whole epibenthic community $\left(\delta^{15} \mathrm{~N}\right.$ for the invertebrate and fish samples combined: Fig. $2 b)$ was $\delta^{15} \mathrm{~N}=12.1+$ $0.388 \log _{2}$ M. Again, this was significant $\left(\mathrm{r}^{2}=0.59, F_{1,68}\right.$ $=97.77, \mathrm{p}<0.001)$. Note that, for the purpose of clarity, the mean $\delta^{15} \mathrm{~N}$ values $( \pm 95 \% \mathrm{CL})$ within body mass classes are presented in Fig. 2, rather than the individual data that were used for the statistical analysis $(\mathrm{n} \geq$ 5 for all body mass classes). All relationships between mean $\delta^{15} \mathrm{~N}$ and $\log _{2}$ body mass were also significant at $\mathrm{p}<0.001$.

Intra-specific relationships between $\delta^{15} \mathrm{~N}$ and body mass were determined for 6 species of invertebrates and 4 species of fishes. For the invertebrates, intra-specific relationships between $\delta^{15} \mathrm{~N}$ and individual body mass were significant for 5 species at $\mathrm{p}<0.05$ and for all 6 species at $\mathrm{p}<0.1$ (Table 1). For fishes, intra-specific relationships between $\delta^{15} \mathrm{~N}$ and individual body mass were significant for 2 of 4 species at $\mathrm{p}<0.05$ and 3 of 4 at $p<0.1$. The intra-specific relationship between $\delta^{15} \mathrm{~N}$ and individual body mass was not significant for Arnoglossus laterna (Table 1).

When the fitted relationships between $\delta^{15} \mathrm{~N}$ and body mass of the most abundant species (Table 1) were plotted on the same scale as the relationship between mass-weighted mean $\delta^{15} \mathrm{~N}$ and body mass for the whole epibenthic community (Fig. 3), it was clear that 
Table 1. Regression parameters and significance of relationships between $\delta^{15} \mathrm{~N}$ and $\log _{2}$ body mass for 6 species of invertebrates and 4 species of fish

\begin{tabular}{|lccrrrrrr|}
\hline Species & $\mathrm{a}$ & $\mathrm{b}$ & $\mathrm{n}$ & $\mathrm{r}{ }^{2}$ & $\mathrm{~F}$ & $\mathrm{df}$ & $\mathrm{p}$ \\
\hline Invertebrates & & & & & & & \\
$\quad$ Ophiura ophiura & 11.8 & 0.309 & 11 & 0.38 & 5.43 & 1,9 & 0.045 \\
Ophiura albida & 12.1 & 0.368 & 11 & 0.41 & 6.34 & 1,9 & 0.033 \\
Astropecten irregularis & 10.5 & 0.198 & 7 & 0.48 & 4.63 & 1,5 & 0.084 \\
Pagurus bernhardus & 11.0 & 0.460 & 13 & 0.68 & 23.55 & 1,11 & $<0.001$ \\
Liocarcinus holsatus & 12.9 & 0.480 & 22 & 0.30 & 8.67 & 1,20 & 0.008 \\
Nephrops norvegicus & 11.3 & 0.489 & 14 & 0.70 & 28.04 & 1,12 & $<0.001$ \\
Fishes & & & & & & & \\
Enchelyopus cimbrius & 12.8 & 0.613 & 17 & 0.47 & 13.40 & 1,15 & 0.002 \\
Arnoglossus laterna & 15.1 & 0.089 & 7 & 0.32 & 2.29 & 1,5 & 0.190 \\
Limanda limanda & 13.4 & 0.280 & 14 & 0.25 & 3.91 & 1,12 & 0.071 \\
Buglossidium luteum & 14.6 & 0.226 & 14 & 0.63 & 20.17 & 1,12 & $<0.001$ \\
\hline
\end{tabular}

exclusion of species outside the 40 to $60 \%$ mass range or inclusion or exclusion of those species for which there was only one replicate made no difference to the significance of our analyses. Mean $\delta^{15} \mathrm{~N}$ for the invertebrate species ranged from 6.4 to $14.2 \%$ (Table 2). The relationship between $\delta^{15} \mathrm{~N}$ and $\log _{2}$ maximum body mass of epibenthic invertebrates (Fig. 4) was not significant $\left(\delta^{15} \mathrm{~N}=0.116 \log _{2} \mathrm{M}+\right.$ 9.98, $\left.\mathrm{r}^{2}=0.03 ; F_{1,40}=1.22 ; \mathrm{p}=0.276\right)$, and neither was the relationship between $\delta^{15} \mathrm{~N}$ and $\log _{2}$ mean body mass $\left(\delta^{15} \mathrm{~N}=0.120 \log _{2} \mathrm{M}+10.1, \mathrm{r}^{2}=\right.$ $0.03 ; F_{1,40}=1.29 ; \mathrm{p}=0.262$ ). The phylogeny for the 42 species we sampled allowed us to calculate 14 contrasts in

the patterns of change in $\delta^{15} \mathrm{~N}$ of abundant species mirrored those of the community. However, the $\delta^{15} \mathrm{~N}$ of abundant species in the same body mass class rarely overlapped.

The analyses of inter-specific relationships between $\delta^{15} \mathrm{~N}$ and body mass were based on 42 invertebrates species recorded in the Silver Pit (Table 2). The mean mass of individuals sampled was 31 to $68 \%$ of maximum recorded mass, although 31 species were within the 40 to $60 \%$ range. For 5 species, only 1 replicate was obtained in the acceptable size range. Inclusion or

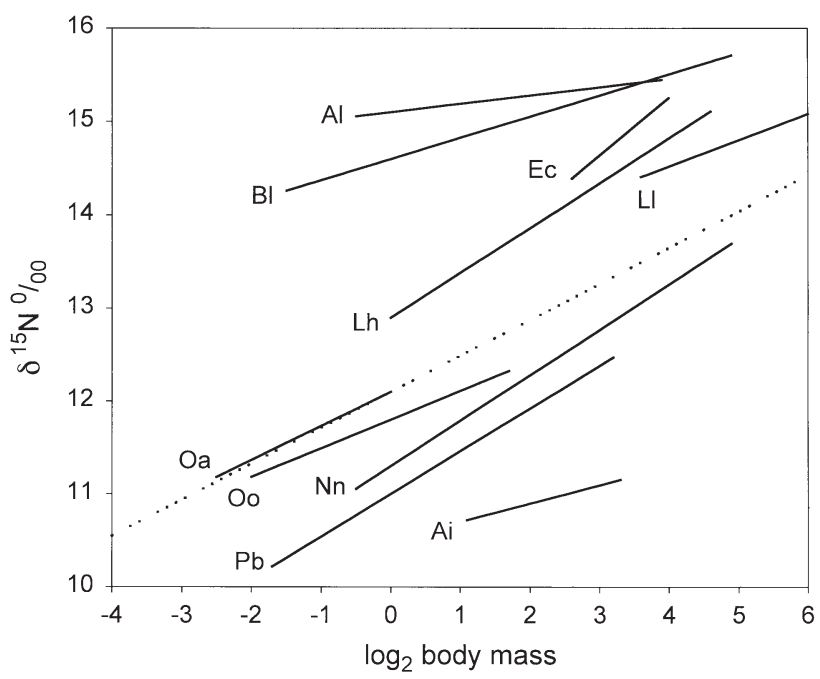

Fig. 3. Fitted linear relationship between the $\delta^{15} \mathrm{~N}$ of invertebrates/fishes and $\log _{2}$ body mass class (dotted line) and fitted linear relationships between the $\delta^{15} \mathrm{~N}$ of individual species of invertebrates or fishes and $\log _{2}$ body mass class (continuous lines). Oo: Ophiura ophiura, Oa: Ophiura albida, Ai: Astropecten irregularis, Pb: Pagurus bernhardus, Lh: Liocarcinus holsatus, Nn: Nephrops norvegicus, Ec: Enchelyopus cimbrius, Al: Arnoglossus laterna, Ll: Limanda limanda, and Bl: Buglossidium luteum $\delta^{15} \mathrm{~N}$ and body mass (Fig. 5). The relationship between contrasts in $\delta^{15} \mathrm{~N}$ and contrasts in $\log _{2}$ maximum body mass was not significant at $\mathrm{p}<0.05$ (Fig. 6; binomial test: 10 positive, 4 negative contrasts, $p>0.1)$, in accordance with the results of the cross-species analysis.

\section{DISCUSSION}

Our analysis of the size and trophic structure of the benthic epifaunal community in the Silver Pit provides empirical evidence, in support of existing theoretical evidence, that the body mass of groups of individuals is a good predictor of their trophic level. This is in accordance with the studies of Fry \& Quinones (1994) and France et al. (1998), and implies that there is a strong empirical link between community analyses based on body size distributions (e.g. Kerr 1974, Boudreau et al. 1991) and trophic structure (e.g. Pimm 1982, Hall \& Raffaelli 1993).

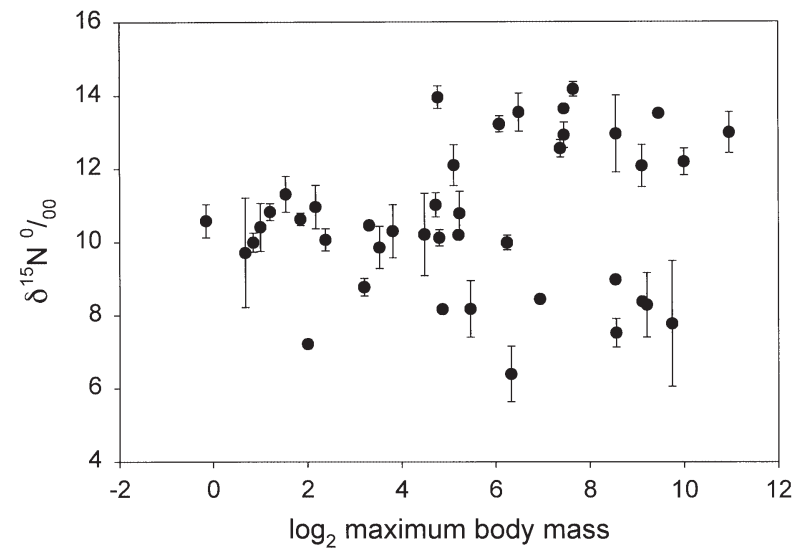

Fig. 4. Relationships between the $\delta^{15} \mathrm{~N}$ (mean $\pm 95 \%$ CL) of 42 epibenthic invertebrate species and their $\log _{2}$ body mass 
Table 2. Invertebrate species used to assess the relationship between body mass and $\delta^{15} \mathrm{~N}$. Mean mass: mean mass of sampled individuals ( ${ }^{*} \mathrm{n}=1$, otherwise $\mathrm{n}=3$ ); Max. mass: mass of the largest individual observed; Mean mass as \% of max.: mean mass of sampled individuals as a percentage of the maximum observed mass

\begin{tabular}{|c|c|c|c|c|}
\hline Species & $\begin{array}{l}\text { Mean mass }(g) \\
(\text { mean } \pm \mathrm{SD})\end{array}$ & Max. mass (g) & $\begin{array}{l}\text { Mean mass as } \\
\% \text { of max. }\end{array}$ & $\begin{array}{c}\delta^{15} \mathrm{~N} \\
(\text { mean } \pm \mathrm{SD})\end{array}$ \\
\hline Aphrodita aculeata & $44.9 \pm 19.55$ & 90.0 & 50 & $13.5 \pm 0.52$ \\
\hline Spirontocarus lilleborgi & $1.2 \pm 0.32$ & 2.3 & 54 & $10.8 \pm 0.23$ \\
\hline Processa canaliculata & $1.0 \pm 0.32$ & 1.6 & 60 & $9.7 \pm 1.49$ \\
\hline Pandalus borealis & $5.7 \pm 0.86$ & 9.9 & 58 & $10.5 \pm 0.10$ \\
\hline Pandalus montagui & $1.9 \pm 0.42$ & 3.6 & 54 & $10.6 \pm 0.17$ \\
\hline Crangon allmani & $0.9 \pm 0.00$ & 2.9 & 31 & $11.3 \pm 0.49$ \\
\hline Pontophilus spinosus & $1.0 \pm 0.12$ & 1.8 & 54 & $10.0 \pm 0.26$ \\
\hline Nephrops norvegicus & $85.4 \pm 14.17$ & 165.7 & 52 & $12.6 \pm 0.24$ \\
\hline Lithodes maja & $600.7 \pm 168.43$ & 1020.0 & 59 & $12.2 \pm 0.37$ \\
\hline Pagurus bernhardus & $42.1 \pm 7.46$ & 67.5 & 62 & $13.2 \pm 0.22$ \\
\hline Pagurus prideaux & $15.6 \pm 3.90$ & 27.8 & 56 & $10.1 \pm 0.22$ \\
\hline Munidia rugosa & $6.3 \pm 0.98$ & 11.5 & 55 & $9.9 \pm 0.57$ \\
\hline Ebalia cranchii & $0.4 \pm 0.06$ & 0.9 & 41 & $10.6 \pm 0.45$ \\
\hline Inarchus dorsettensis & $15.8 \pm 0.71$ & 27.3 & 58 & $14.0 \pm 0.31$ \\
\hline Corystes cassevelinus & $19.0 \pm 2.03$ & 34.5 & 55 & $12.1 \pm 0.56$ \\
\hline Atelecyclus rotundatus & $11.8 \pm 3.12$ & 22.3 & 53 & $10.2 \pm 1.12$ \\
\hline Cancer pagurus & $863.3 \pm 163.57$ & 1985.0 & 43 & $13.0 \pm 0.56$ \\
\hline Liocarcinus depurator & $21.7 \pm 4.74$ & 36.9 & 59 & $10.2 \pm 0.06$ \\
\hline Liocarcinus holsatus & $15.4 \pm 3.57$ & 26.4 & 58 & $11.0 \pm 0.33$ \\
\hline Colus gracilis & $21.3 \pm 2.17$ & 37.4 & 57 & $10.8 \pm 0.60$ \\
\hline Buccinum undatum & $125.3 \pm 18.49$ & 201.0 & 62 & $14.2 \pm 0.20$ \\
\hline Neptunia antiqua & $187.5 \pm 44.16$ & 375.8 & 50 & $13.0 \pm 1.05$ \\
\hline Polinices montagui & $3.0 \pm 0.87$ & 5.2 & 58 & $10.1 \pm 0.30$ \\
\hline Modiolis modiolis & $287.0^{*}$ & 552.0 & 52 & 8.4 \\
\hline Aequipecten opercularis & $40.7 \pm 4.70$ & 80.0 & 51 & $6.4 \pm 0.76$ \\
\hline Loligo forbesi & $369.3 \pm 109.35$ & 550.5 & 67 & $12.1 \pm 0.58$ \\
\hline Loligo vulgaris & $59.0^{*}$ & 175.0 & 34 & 13.6 \\
\hline Eledone cirrhosa & $367.0^{*}$ & 704.0 & 52 & 13.5 \\
\hline Luidia ciliaris & $205.3^{*}$ & 373.0 & 55 & 9.0 \\
\hline Astropecten irregularis & $29.8 \pm 6.47$ & 44.0 & 68 & $8.2 \pm 0.77$ \\
\hline Porania pulvillus & $41.4 \pm 12.47$ & 75.5 & 55 & $10.0 \pm 0.20$ \\
\hline Asterina gibbosa & $98.0 \pm 23.90$ & 175.0 & 56 & $12.9 \pm 0.35$ \\
\hline Henricia sanguinolenta & $18.0^{*}$ & 29.1 & 62 & 8.2 \\
\hline Asterias rubens & $175.3 \pm 28.01$ & 376.5 & 47 & $7.5 \pm 0.39$ \\
\hline Leptasterias muelleri & $47.0^{*}$ & 122.6 & 38 & 8.4 \\
\hline Ophiothrix fragilis & $5.9 \pm 0.40$ & 9.2 & 64 & $8.8 \pm 0.24$ \\
\hline Ophiura albida & $1.3 \pm 0.10$ & 2.0 & 65 & $10.4 \pm 0.65$ \\
\hline Ophiura ophiura & $2.9 \pm 0.10$ & 4.5 & 64 & $11.0 \pm 0.59$ \\
\hline Echinus acutus & $238.0 \pm 231.62$ & 590.0 & 40 & $8.3 \pm 0.88$ \\
\hline Echinus elegans & $1.7 \pm 0.17$ & 4.0 & 43 & $7.2 \pm 0.13$ \\
\hline Echinus esculentus & $411.3 \pm 137.41$ & 855.0 & 48 & $7.8 \pm 1.72$ \\
\hline Psamechinus miliaris & $9.3 \pm 3.51$ & 14.0 & 67 & $10.3 \pm 0.72$ \\
\hline
\end{tabular}

The increase in trophic level with increasing body mass within the community is a response to intraspecific increases in trophic level with increasing body mass rather than, at an inter-specific level, the higher trophic levels of species with larger body mass. Comparison of changes in trophic level with body mass for the invertebrate and fish community suggest that competition for food between invertebrates and fishes of similar body mass is low, since the $\delta^{15} \mathrm{~N}$ of invertebrates is generally $2 \%$ lower than that of fishes of the same mass. Among the most abundant species, the relationships between $\delta^{15} \mathrm{~N}$ and body mass suggests that abundant species have separate feeding niches. Given that the $\delta^{15} \mathrm{~N}$ of the whole community increased consistently with body size, our results imply that species have evolved to feed at many trophic levels, but that small species feeding at high trophic levels will always be relatively scarce. Patterns at the community level are consistent with the expectation that predator-prey relationships led to powerful size-based trophic structuring.

If $\delta^{15} \mathrm{~N}$ increases linearly with trophic level then the strength of relationships between $\delta^{15} \mathrm{~N}$ and $\log _{2}$ body 


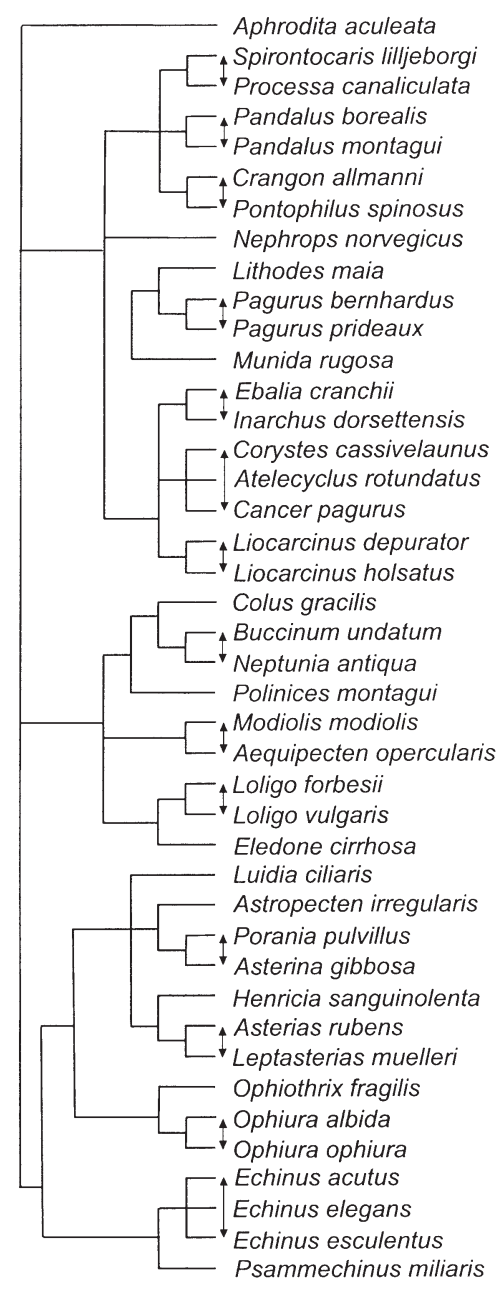

Fig. 5. Phylogenetic relationships among 42 species of epibenthic invertebrates for which $\delta^{15} \mathrm{~N}$ and maximum body mass estimates were available. Branch lengths were set to unity and vertical arrows indicate paired comparisons among species

mass class will reflect the strength of relationships between trophic level and $\log _{2}$ body mass class. If we assume a $\delta^{15} \mathrm{~N}$ enrichment of $3.4 \%$ for each trophic step (Minawaga \& Wada 1984), then we can estimate the mean predator:prey body mass ratio in this benthic community as $2^{3.4 / s l o p e}$ or $434: 1$. However, the assumed $\delta^{15} \mathrm{~N}$ enrichment of $3.4 \%$ is a mean of many reported values (Minawaga \& Wada 1984, Adams \& Sterner 2000), and this has prompted calls for experimental evaluation and validation (Gannes et al. 1997, Pinnegar \& Polunin 1999, Ponsard \& Averbuch 1999, Schoella 1999). We cannot provide such validation for the range of complex feeding relationships that apply to the species included in this study, and regard the mean predator:prey body mass ratio as a tentative value.

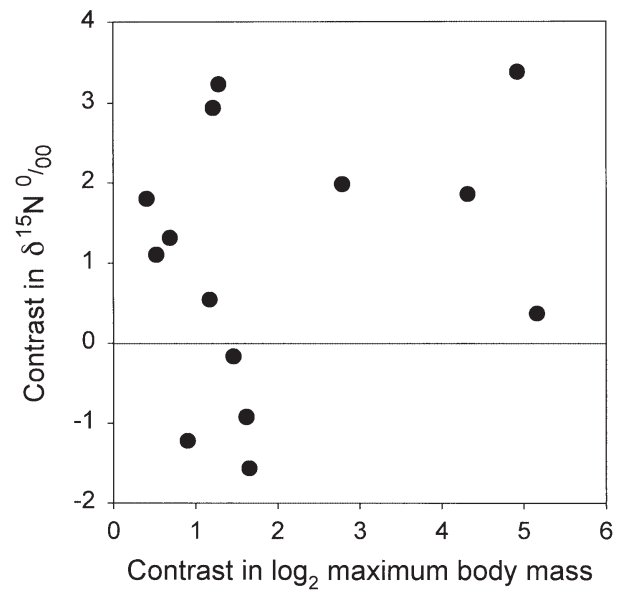

Fig. 6. Relationships between contrasts in $\delta^{15} \mathrm{~N}$ and contrasts in $\log _{2}$ body mass of epibenthic invertebrates

The observed relationship between $\delta^{15} \mathrm{~N}$ and body mass, and thus the mean predator:prey body mass ratio, will be influenced by the strength of feeding relationships between the community we sampled and species we did not sample. Benthic infauna are expected to account for a large proportion of biomass and production in muddy-sand habitats, and do not consistently increase in trophic level with body size because many of the largest infaunal species are filterand deposit-feeding bivalves. However, the role of these bivalves in the size-based epifaunal food webs we studied is far from clear. The largest bivalves are unlikely to be widely eaten by epifauna, since species such as Arctica islandica have very low natural mortality and great longevity (100+ yr) (Witbaard et al. 1999). This implies that their role in benthic food webs is more likely to be associated with the production of excreted material that can be utilised by bacteria and meiofauna. Indeed, large bivalves may only become accessible to predators when they are damaged by impacts from towed fishing gears or when flatfish such as plaice bite off their siphons (Rumohr \& Krost 1991, Witbaard \& Klein 1994). The infauna most widely available to fishes and epibenthic species are the smaller bivalves and polychaetes. Some of the polychaetes already feed at trophic levels comparable with those of epibenthic species of a similar body mass (Jennings et al. 2001). This is because the polychaetes feed on smaller polychaetes and meiofauna as well as microbially enriched detritus (Schubert \& Reise 1986, Beukema 1987).

Size-based models of some marine communities and ecosystems are relatively straightforward to develop because estimates of biomass by body mass class can be obtained from existing plankton, invertebrate or fisheries survey data (e.g. Pope et al. 1988). If relation- 
ships between body mass and trophic level are consistent in space and time, these relationships could be used to predict the trophic levels of body mass classes in the size spectrum. This approach would be analagous to the existing parameterisation of size spectra with production to biomass ratios (e.g. Schwinghamer et al. 1986, Duplisea 1998). A size spectrum parameterised with trophic levels would provide a description of trophic structure, and changes in the gradient of the spectrum would reflect changes in mean trophic level. The resulting trophic spectra would have several possible applications. For example, analyses of temporal and spatial changes in size spectra could be used to detect temporal and spatial changes in trophic structure and to assess the impacts of disturbance.

Acknowledgements. We wish to thank Tracy Dinmore, Brian Edwards, Chris Firmin, Derek Eaton, Roger Flatt, Paul Hudson, Steve Lovewell, Tracy Mead, Dave Palmer, Michaela Schratzberger, Christie Stewart, Peter Walker and the officers and crew of RV 'Corystes' for their efforts at sea, Gillian Taylor and Rowan White for the stable isotope analyses, 3 anonymous referees for a number of helpful suggestions and CEFAS (DP166) and MAFF (MF0716) for funding this research.

\section{LITERATURE CITED}

Adams TS, Sterner RW (2000) The effect of dietary nitrogen content on trophic level ${ }^{15} \mathrm{~N}$ enrichment. Limnol Oceanogr 45:601-607

Beukema JJ (1987) Influence of the predatory polychaete Nephtys hombergii on the abundance of other polychaetes. Mar Ecol Prog Ser 40:95-101

Beverton RJH, Holt SJ (1959) A review of the lifespan and mortality rates of fish in nature and their relationship to growth and other physiological characteristics. Ciba Found Colloq Ageing 5:142-180

Boudreau PR, Dickie LM, Kerr SR (1991) Body-size spectra of production and biomass as system-level indicators of ecological dynamics. J Theor Biol 152:329-339

Boyle PR, Bolettzky Sv (1996) Cephalopod populations: definition and dynamics. Philos Trans R Soc Lond B Biol Sci 351: 985-1002

Boyle PR, Pierce GJ (1994) Fishery biology of northeast Atlantic squid: an overview. Fish Res (Amst) 21:1-16

Brey T (1990) Estimating productivity of macrobenthic invertebrates from biomass and mean individual weight. Meeresforschung 32:329-343

Brey T (1999) Growth performance and mortality in aquatic macrobenthic invertebrates. Adv Mar Biol 35:153-223

Cabana G, Rasmussen JB (1996) Comparison of aquatic food chains using nitrogen isotopes. Proc Natl Acad Sci USA 93:10844-10847

Charnov EL (1993) Life history invariants: some explorations of symmetry in evolutionary ecology. Oxford University Press, Oxford

Cohen JE, Pimm SL, Yodzis P, Saldaña J (1993) Body sizes of animal predators and animal prey in food webs. J Anim Ecol 62:67-78

Cushing DH (1975) Marine ecology and fisheries. Cambridge University Press, Cambridge, UK
Dickie LM, Kerr SR, Boudreau PR (1987) Size-dependent processes underlying regularities in ecosystem structure. Ecol Monogr 57:233-250

Duplisea DE (1998) Structuring of benthic communities with a focus on size spectra. Ph D thesis, Stockholm University

Duplisea DE, Kerr SR (1995) Application of a biomass size spectrum model to demersal fish data from the Scotian shelf. J Theor Biol 177:263-269

Felsenstein J (1985) Phylogenies and the comparative method. Am Nat 125:1-15

France R, Chandler M, Peters R (1998) Mapping trophic continua of benthic food webs: body size $\delta^{15} \mathrm{~N}$ relationships. Mar Ecol Prog Ser 174:301-306

Freckleton RP (2000) Phylogenetic tests of ecological and evolutionary hypotheses: checking for phylogenetic independence. Funct Ecol 14:129-134

Fry B, Quinones RB (1994) Biomass spectra and stable-isotope indicators of trophic level in zooplankton of the northwest Atlantic. Mar Ecol Prog Ser 112:201-204

Fry B, Sherr EB (1984) $\delta^{13} \mathrm{C}$ measurements as indicators of carbon flow in marine and freshwater ecosystems. Contrib Mar Sci 27:13-47

Gannes L, O'Brien D, del Rio C (1997) Stable isotopes in animal ecology: assumptions, caveats, and a call for more laboratory experiments. Ecology 78:1271-1276

Gunderson DR, Dygert PH (1988) Reproductive effort as a predictor of natural mortality rate. J Cons Int Explor Mer 44:200-209

Hall SJ, Raffaelli DG (1993) Food webs: theory and reality. Adv Ecol Res 24:187-239

Harvey PH, Pagel MD (1991) The comparative method in evolutionary biology. Oxford University Press, Oxford

Hayward PJ, Ryland JS (1990a) The marine fauna of the British Isles and north-western Europe. Vol. 1. Introduction and protozoans to arthropods. Clarendon Press, Oxford

Hayward PJ, Ryland JS (1990b) The marine fauna of the British Isles and north-western Europe. Vol. 2. Molluscs to chordates. Clarendon Press, Oxford

Hentschel B (1998) Intraspecific variations in $\delta^{13} \mathrm{C}$ indicate ontogenetic diet changes in deposit-feeding polychaetes. Ecology 79:1357-1370

Hobson KA, Welch HE (1992) Determination of trophic relationships within a high arctic marine food web using $\delta^{13} \mathrm{C}$ and $\delta^{15} \mathrm{~N}$ analysis. Mar Ecol Prog Ser 84:9-18

Howson CM, Picton BE (1997) The species directory of the marine fauna and flora of the British Isles and surrounding seas. Ulster Museum and Marine Conservation Society, Belfast and Ross on Wye

ICES (1999) Report of the study group to evaluate the effects of multispecies interactions. Int Counc Explor Sea, Comm Meet 1999/D:4

Jennings S, Reynolds JD, Mills SC (1998) Life history correlates of responses to fisheries exploitation. Proc R Soc Lond Ser B Biol Sci 265:333-339

Jennings S, Lancaster JE, Woolmer A, Cotter AJ (1999) Distribution, diversity and abundance of epibenthic fauna in the North Sea. J Mar Biol Assoc UK 79:385-399

Jennings S, Pinnegar JK, Polunin NVC, Warr KJ (2001) Impacts of trawling disturbance on the trophic structure of benthic invertebrate communities. Mar Ecol Prog Ser 213: 127-142

Kerr SR (1974) Theory of size distribution in ecological communities. J Fish Res Board Can 31:1859-1862

Kingsford MJ (1992) Spatial and temporal variation in predation on reef fishes by coral trout (Plectropomus leopardus, Serranidae). Coral Reefs 11:193-198 
Lindsay DJ, Minagawa M, Mitani I, Kawaguchi K (1998) Trophic shift in the Japanese Anchovy Engraulis japonicus in its early life history stages, as detected by stable isotope ratios in Sagami Bay, central Japan. Fish Sci (Tokyo) 64: 403-410

Magnússon KG (1995) An overview of the multispecies VPAtheory and applications. Rev Fish Biol Fish 5:195-212

Minawaga M, Wada E (1984) Stepwise enrichment of ${ }^{15} \mathrm{~N}$ along food chains: further evidence and the relation between ${ }^{15} \mathrm{~N}$ and animal age. Geochem Cosmochim Acta 48:1135-1140

Owens NJP (1987) Natural variations in ${ }^{15} \mathrm{~N}$ in the marine environment. Adv Mar Biol 24:389-451

Pauly D (1980) On the interrelationships between natural mortality, growth parameters and mean environmental temperature in 175 fish stocks. J Cons Int Explor Mer 39: 175-192

Persson A, Hansson LA (1999) Diet shift in fish following competitive release. Can J Fish Aquat Sci 56:70-78

Peters RH (1983) The ecological implications of body size. Cambridge University Press, Cambridge, UK

Peterson BJ, Fry B (1987) Stable isotopes in ecosystem studies. Ann Rev Ecol Syst 18:293-320

Peterson BJ, Howarth RW, Garritt RH (1985) Multiple stable isotopes used to trace the flow of organic matter in estuarine food webs. Science 227:1361-1363

Pimm SL (1982) Food webs. Chapman \& Hall, London

Pinnegar JK, Polunin NVC (1999) Differential factionation of $\delta^{13} \mathrm{C}$ and $\delta^{15} \mathrm{~N}$ among fish tissues: implications for the study of trophic interactions. Funct Ecol 13:225-231

Polunin NVC, Pinnegar JK (2002) Ecology of fishes in marine food-webs. In: Hart PJ, Reynolds JD (eds) Handbook of fish and fisheries. Blackwell, Oxford (in press)

Ponsard S, Averbuch P (1999) Should growing and adult animals fed on the same diet show different $\delta^{15} \mathrm{~N}$ values? Rapid Comm Mass-Spectrometry 13:1305-1310

Pope JG, Stokes TK, Murawski SA, Iodoine SI (1988) A comparison of fish size composition in the North Sea and on Georges Bank. In: Wolff W, Soeder CJ, Drepper FR (eds) Ecodynamics: contributions to theoretical ecology. Springer-Verlag, Berlin, p 146-152

Post DM, Pace ML, Hairston NG (2000) Ecosystem size determines food-chain length in lakes. Nature 405:1047-1049

Preston T (1992) The measurement of stable isotope natural abundance variations. Plant Cell Environ 15:1091-1097

Preston T, Owens NJP (1983) Interfacing an automatic elemental analyser with an isotope ratio mass spectrometer: the potential for fully automated total nitrogen and nitrogen-15 analysis. Analyst (Lond) 108:971-977

Rau GH, Mearns AJ, Young DR, Olson RJ, Schafer HA, Kaplan IR (1983) Animal ${ }^{13} \mathrm{C} /{ }^{12} \mathrm{C}$ correlates with trophic level in pelagic food webs. Ecology 64:1314-1318

Reynolds JD, Jennings S, Dulvy NK (2001) Life histories of fishes and population responses to exploitation. In:

Editorial responsibility: Otto Kinne (Editor),

Oldendorf/Luhe, Germany
Reynolds JD, Mace GM, Redford KH, Robinson JG (eds) Conservation of exploited species. Oxford University Press, Oxford

Rice J, Gislason H (1996) Patterns of change in the size spectra of numbers and diversity of the North Sea fish assemblage, as reflected in surveys and models. ICES J Mar Sci 53:1214-1225

Rumohr H, Krost P (1991) Experimental evidence of damage to the benthos by bottom trawling with special reference to Arctica islandica. Meeresforschung 33:340-345

Schoella D (1999) Isotope fractionation: why aren't we what we eat? J Archaeol Sci 26:667-673

Schubert A, Reise K (1986) Predatory effects of Nephtys hombergii on other polychaetes in tidal sediments. Mar Ecol Prog Ser 34:117-124

Schwinghamer P, Hargrave B, Peer D, Hawkins CM (1986) Partitioning of production and respiration among size groups of organisms in an intertidal benthic community. Mar Ecol Prog Ser 31:131-142

Sheldon RW, Prakash A, Sutcliffe WH (1972) The size distribution of particles in the ocean. Limnol Oceanogr 17: $327-340$

Sholtodouglas AD, Field JG, James AG, Vandermerwe NJ (1991) ${ }^{13} \mathrm{C} /{ }^{12} \mathrm{C}$ and ${ }^{15} \mathrm{~N} /{ }^{14} \mathrm{~N}$ isotope ratios in the southern Benguela ecosystem-indicators of food web relationships among different size classes of plankton and pelagic fish differences between fish muscle and bone-collagen tissues. Mar Ecol Prog Ser 78:23-31

Thiebaux ML, Dickie LM (1992) Models of aquatic biomass size spectra and the common structure of their solutions. J Theor Biol 159:147-161

Thiebaux ML, Dickie LM (1993) Structure of the body size spectrum of the biomass in aquatic ecosystems: a consequence of allometry in predator-prey interactions. Can J Fish Aquat Sci 50:1308-1317

Vander Zanden M, Cabana G, Rasmussen JB (1997) Comparing trophic position of freshwater fish calculated using stable nitrogen isotope ratios $\left(\delta^{15} \mathrm{~N}\right)$ and literature dietary data. Can J Fish Aquat Sci 54:1142-1158

Vander Zanden MJ, Casselman JM, Rasmussen JB (1999) Stable isotope evidence for the food web consequences of species invasions in lakes. Nature 401:464-467

Wainwright SC, Fogarty MJ, Greenfield RC, Fry B (1993) Long term changes in the Georges Bank food web: trends in stable isotopic composition of fish scales. Mar Biol 115: 481-493

Witbaard R, Klein R (1994) Long-term trends on the effects of the southern North Sea beam trawl fishery on the bivalve mollusc Arctica islandica L. (Mollusca, Bivalvia). ICES J Mar Sci 51:99-105

Witbaard R, Duineveld GCA, de Wilde PAWJ (1999) Geographical differences in growth rates of Arctica islandica (Mollusca: Bivalvia) from the North Sea and adjacent waters. J Mar Biol Assoc UK 79:907-915

Submitted: April 25, 2001; Accepted: July 31, 2001

Proofs received from author(s): January 11, 2002 